tell-tale signs of the heating that each part experienced, says Arvid Pasto, director of the High Temperature Materials Laboratory at Oak Ridge National Laboratory in Tennessee. Knowing the shape and conductivity of the shuttle's components will also allow the spreading of heat throughout the craft to be modelled. And if pieces are missing, they probably either blew apart or were vaporized, again giving clues as to where fires broke out.

NASA is likely to send debris to Oak Ridge for such tests, says Pasto. Parts that experienced the most heating were probably situated close to where the malfunction originated. But the ultimate goal, he says, is to simulate the heat to which all of the individual pieces were exposed and then reconstruct the entire break-up with the aid of a supercomputer.

NASA staff will check their break-up models with radar and satellite images of the disintegrating shuttle and the wealth of photos and videos taken by the public and astronomers. They will also make use of data from the shuttle's autopilot, which took corrective action to counter a drag on the left wing minutes before the craft broke up. Models of the shuttle's aerodynamics could shed light on what caused the autopilot to take the action that it did.

Little other concrete information about the moments before the accident has emerged so far. Just before contact with the craft was lost, mission control detected temperatures rising by around $2{ }^{\circ} \mathrm{C}$ per minute in the well that contains the wheel on the left wing. Temperatures across the wing and fuselage then rose, and sensors of pressure, temperature and other parameters failed.

The investigation is still in its evidencegathering phase, says Waldock, and firm conclusions are weeks, if not months, away.

\title{
DNA study deepens rift over Iceland's genetic heritage
}

\section{Alison Abbott}

The row between Icelandic company deCODE Genetics and its opponents has been rekindled by an analysis of European DNA sequences.

Based in Reykjavik, deCODE has claimed that Icelanders are relatively genetically homogeneous, and that analysis of the population's sequence data and medical history should therefore aid the hunt for diseaserelated genes. To those ends, the Icelandic parliament granted deCODE exclusive access to the medical records of the country's inhabitants. Opponents such as lobby group Mannvernd object to the commercial use of Iceland's medical records.

The claims for Iceland's homogeneity made by deCODE are based on results published over the past few years. Researchers at the company and at the University of Oxford, UK, compared the sequences of mitochondrial DNA samples from about 400 Icelanders with those from other nationalities stored in various sequence databases (A. Helgason et al. Am. J. Hum. Genet. 66, 999-1016; 2000).

Einar Árnason, a geneticist at the University of Iceland in Reykjavik and a member of Mannvernd's board, now says that deCODE's researchers were misled by extensive errors in some of the databases they used in their analysis. He also questions a few of the assumptions behind the technique the company used to compare the sequences.

Ârnason re-analysed available data, but avoided using databases. He compared mitochondrial DNA sequences generated by his research group and by deCODE, and compared them with data in research papers on 26 different European populations. His results suggest that several characteristics of the mitochondrial DNA sequences vary as much in Iceland as they do in the rest of Europe (E. Árnason Ann. Hum. Genet. 67, 5-16;2003).

Scientists at deCODE do not dispute Árnason's sequence data, but say that he has misinterpreted them. The firm's chief executive, Kári Stefánsson, says that the database errors have only a "limited" effect on Iceland's position in the hierarchy of European genetic homogeneity. The company adds that Iceland's extensive genealogical data will aid the hunt for disease genes, whatever the genetic variation within the country's population proves to be.

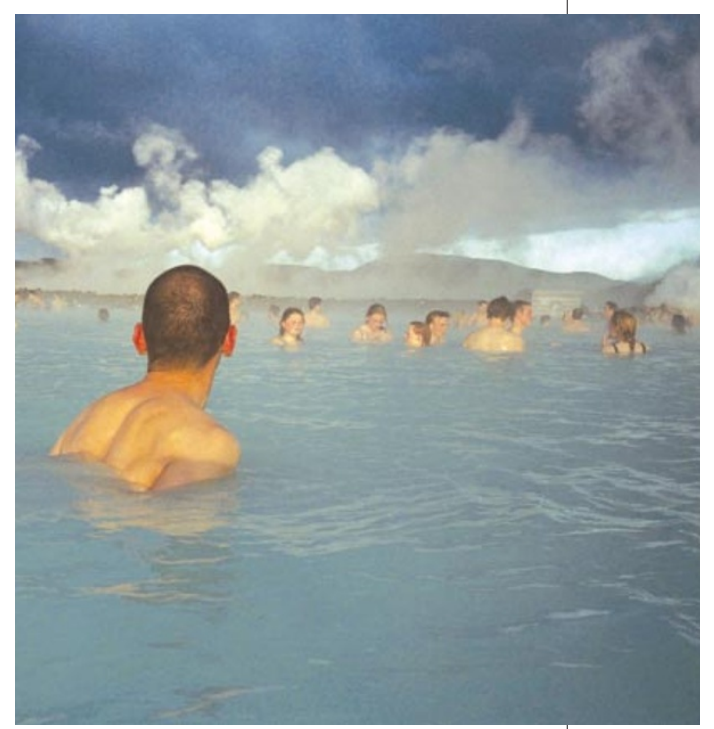

All mixed up: Icelanders may be as genetically heterogeneous as the rest of Europe.

\section{Cancer fears cast doubts on future of gene therapy}

\section{Erika Check, Washington}

A once-promising gene-therapy treatment should be used only as a last resort, advisers to the US National Institutes of Health (NIH) said this week.

Members of the NIH's Recombinant DNA Advisory Committee, meeting in Bethesda, Maryland, on 10 February, said that patients suffering from severe combined immunodeficiency disease (SCID) should be treated by gene therapy only if they fail to respond to all other treatments. SCID, which disrupts the development of the immune system, is the only disease so far to have been cured by gene therapy.

SCID trials in the United States were suspended last year by the Food and Drug Administration (FDA) after a child in the world's most advanced study, led by Alain Fischer of the Necker Hospital for Sick Children in Paris, developed leukaemia. The agency halted 24 similar gene-therapy trials when a second child in Fischer's trial was diagnosed with leukaemia in December (see Nature 421, 305; 2003).

In both cases, the retrovirus used to deliver the corrective gene to the patient inserted itself into a stretch of DNA in or near a gene called $\mathrm{LMO} 2$, which can cause childhood leukaemia. Since then, Christof von Kalle, a molecular geneticist at the Cincinnati Children's Hospital, has found that a similar insertion has occurred in a third child in Fischer's study, although this patient has not developed leukaemia.

The committee's advice to limit the use of SCID gene therapy is expected to influence the FDA's final decision on the US trials. The agency will consider whether to halt the SCID trials permanently when its advisory committee meets on 28 February.

Scientists say that this meeting is crucial for the future of gene therapy. "People are very worried that these cases will shut down the entire field of gene transfer," says Diane Wara, a paediatrician at the University of California, San Francisco, who sits on the NIH committee. 